\title{
Fusion inhibitors and their evolving role during salvage antiretroviral therapy. Seven years of experience with enfuvirtide
}

Roberto Manfredi

From $16^{\text {th }}$ International Symposium on HIV and Emerging Infectious Diseases

Marseille, France. 24-26 March 2010

\section{Background}

The need of rescue antiretroviral regimens is progressively increasing, due to the unavoidable long-term emerging of multiresistant HIV strains.

\section{Methods}

An open-label study featuring the administration of the fusion inhibitor enfuvirtide (T-20) as a part of salvage anti-HIV regimens in a cohort of hardly pre-treated and multiresistant patients (p) with advanced HIV disease, followed until at least three consecutive years, is presented.

\section{Results}

The efficacy and safety parameters of enfuvirtide adjunct to an optimized background were assessed monthly in 21 severely compromised $\mathrm{p}$, with a baseline viremia ranging from 64,000 to over 500,000 HIV-RNA copies/mL, and a $\mathrm{CD} 4+$ lymphocyte count ranging from 11 to 213 cells $/ \mu \mathrm{L}$. At the time of enfuvirtide introduction, the background antiretroviral therapy was modified according to both genotypic-virtual phenotypic resistance assays, but only 15 of $21 \mathrm{p}$ could rely on at least one in vitro effective drug (during the first years of our experience, raltegravir, maraviroc, etravirine, riplpivirine, and also tipranavir and darunavir were not still available). Anyway, a rapid and significant drop of viremia (at least one $\log _{10}$ HIV-RNA copies $/ \mathrm{mL}$ ), associated with a $30-280 \%$ increase of CD4+ cell count versus baseline values was observed in all $\mathrm{p}$, although 13 our of $15 \mathrm{p}$ who could rely on an optimized background had a sustained response (12-36 months). In $11 \mathrm{p}$, a surprising dissociation between a favorable virological response and a progressive loss of CD4+ cells was observed. Although frequent, local injection site adverse

Correspondence: Roberto.manfredi@unibo.it

Infectious Diseases, University of Bologna, S. Orsola Hospital, Bologna, Italy effects never represented the major cause of enfuvirtide interruption.

\section{Discussion}

Expectations and concerns on the use of enfuvirtide as a novel anti-HIV compound in daily practice are still debated, since no specific recommendations have been produced (especially with regard with the novel, available compounds), when excluding the assumption that enfuvirtide appears significantly more effective when administered concurrently with at least 1-2 other active antiretrovirals, although the reported experiences often included $\mathrm{p}$ on very advanced salvage therapies. The management of the frequent site injection reactions represents an adjunctive concern for these multi-problematic HIV-infected p.

\section{Published: 11 May 2010}

\section{doi:10.1186/1742-4690-7-S1-P52}

Cite this article as: Manfredi: Fusion inhibitors and their evolving role during salvage antiretroviral therapy. Seven years of experience with enfuvirtide. Retrovirology 2010 7(Suppl 1):P52.

Submit your next manuscript to BioMed Central and take full advantage of:

- Convenient online submission

- Thorough peer review

- No space constraints or color figure charges

- Immediate publication on acceptance

- Inclusion in PubMed, CAS, Scopus and Google Scholar

- Research which is freely available for redistribution

Submit your manuscript at www.biomedcentral.com/submit 